\title{
Long Term Benefit of Autologous Bone Marrow Stem Cell Transplantation without Immunosuppression in Chronic Type 1 Diabetic Patients
}

\author{
Alejandro Mesples ${ }^{1 *}$, Yun Zhang ${ }^{2}$, Xiang Hu \\ ${ }^{1}$ Diabetes Education and Research, Buenos Aires, Argentina \\ ${ }^{2}$ Shenzhen Beike Cell Engineering Research Institute, Shenzhen, China \\ Email: ^amesples@yahoo.com.ar, publication@beikebiotech.com
}

How to cite this paper: Mesples, A., Zhang, Y. and $\mathrm{Hu}, \mathrm{X}$. (2020) Long Term Benefit of Autologous Bone Marrow Stem Cell Transplantation without Immunosuppression in Chronic Type 1 Diabetic Patients. Stem Cell Discovery, 10, 1-14. https://doi.org/10.4236/scd.2020.101001

Received: August 5, 2019

Accepted: January 27, 2020

Published: January 30, 2020

\section{Copyright $\odot 2020$ by author(s) and} Scientific Research Publishing Inc. This work is licensed under the Creative Commons Attribution International License (CC BY 4.0).

http://creativecommons.org/licenses/by/4.0/ (c) (i) Open Access

\begin{abstract}
Background: Autologous bone marrow stem cell transplantation without immune suppression has been proposed as a safe and efficient therapeutic option to replace $\beta$-cell mass destroyed by specific antibodies in chronic type 1 diabetes but we have not scientific information about how long the metabolic stability is maintained. Material and Method: From 2010 to 2014, were included 134 chronic type 1 diabetics patients (p.) in an autologous bone marrow stem cell transplantation protocol, stimulated with filgrastim, without immune suppression, c peptide $<0.5 \mathrm{ng} / \mathrm{ml}$ and pancreatic antibodies negatives, without diabetes complications. 65 Female and 69 Male patients, with $36+20$ years old and insulin-dependent were treated. Follow up variables, c peptide, $\mathrm{A} 1 \mathrm{C}$, pancreatic islets and GAD antibodies and insulin dose at 6, 12, 24 and 36 months were performed. Results: C peptide, 6 months after transplantation more than $0.9 \mathrm{ng} / \mathrm{ml}$ in 61 patients $(45 \%)(\mathrm{P}=0.001, \mathrm{CI}=$ 95\%). At 12 months 50 patients $(37 \%)(\mathrm{P}=0.001, \mathrm{CI}=95 \%)$. At 24 months 53 patients $(39 \%)(\mathrm{P}=0.001, \mathrm{CI}=95 \%)$. At 36 months 51 patients $(38 \%)(\mathrm{P}=$ $0.001, \mathrm{CI}=95 \%)$. A1C before transplant, $<7 \%$ was observed in $25 \mathrm{p} .(18 \%)$. At 6 months 68 p. (50\%), 12 months 90 p. (67\%), 24 months 92 p. (68\%), at 36 months in 85 p. (63\%) Patients without Insulin dose, at 6 months $61 \mathrm{p}$. (45\%), 12 months 60 p. (44\%), 24 months 58 p. (43\%), at 36 months in 53 p. (39\%). No evidence of new pancreatic antibodies or adverse events. Conclusion: Autologous bone marrow stem cell transplantation, without immunosuppression, improves pancreatic function and metabolic control without new immune reaction after three years of follow up in chronic type 1 diabetic patients.
\end{abstract}




\section{Keywords}

Type 1 Diabetes, Bone Marrow Transplantation, Bone Marrow Stem Cells

\section{Introduction}

In type 1 diabetes, significant destruction of b-cells by specific antibodies occurs prior to diagnosis. At the time of clinical onset, only $10 \%$ of normal b-cell mass remains [1]. Several studies show that C-peptide measurement is the best way to observe endogenous pancreatic function. A prospective study found that 2 years after diagnosis, insulin and C-peptide levels decreased to nearly $30 \%$ of baseline [2] [3]. Studies show that patients with advanced disease have some residual b-cell function, depending on individual variables [4] [5] [6] [7]. Low or vanished C-peptide levels are indicative of advancing disease after a diagnosis, and undetectable C-peptide is usually observed after 1 year of disease duration. Recent studies have been trying to replace the functional mass of pancreatic islets destroyed by the autoimmune attack in type 1 diabetes [8] [9] [10] [11]. Pancreas and pancreatic islets transplantations are two alternatives under consideration [12] [13]. However, the low availability of donors, the technical complexity, immune suppression after transplantation and the uncertain treatment results are the most important complications. Several studies have described the regenerative capacity of stem cells, which can repair the cellular injury in all tissues. The mechanisms of stem cell migration, adhesion and differentiation mediated by local chemokines were reported in several publications [14] and the capacity of these adult stem cells to differentiate into cells of such cardiomyocyte, hepatocytes and renal cells [15] [16] [17] [18].

We have many backgrounds describing the differentiation of stem cells in pancreatic $\beta$ cells and mechanisms for the regenerative repair of B cells. Early studies indicated that adult pancreatic endocrine cells can be regenerated by the automatic duplication of differentiated cells [19]. Immunohistochemical observations also suggest an origin of stem cells for islet cells, including $\beta 4$ cells expressing insulin. Other authors demonstrated that adult pancreatic stem or progenitor cells reside in the epithelium of the pancreatic ducts, [20] within the islets or in the bone marrow [14]. Others have suggested that $\beta$ cells are formed by transdifferentiation of pancreatic acinar cells. In addition to explaining the formation of new $\beta$ cells within the existing islets, it has also been suggested that new complete islets are formed (neogenesis) by grouping the new $\beta$ cells from stem cells [21] [22].

The use of adult stem cells in myocardial infarction showed a significant improvement in ventricular function [23] [24] [25] [26] [27]. Stem cell transplants in blood malignancies such as leukemias demonstrated safety and efficacy [28] [29]. Similarly in osteoarthritis [30] [31] and peripheral vascular disease [32] [33] [34] [35] using bone marrow stem cells showed significant benefit security and to suppress pain and improve functional capacity. In type 1 diabetes recent 
diagnosis reported significant increases in C-peptide after transplantation of allogeneic adult stem cells with immune suppression [36] [37] [38].

Our workgroup began its experience in 2005, with a first clinical trial on autologous bone marrow transplantation stimulated with filgrastim in chronic diabetic patients, who underwent infusion of the bone marrow by selective catheterization of the pancreatic artery [39]. In this first trial, we included 20 patients with a follow-up of 36 months [40]. In 2010 we modified the technique achieving a significant increase in the extracted volume, we improved the numbers of cells recovered from the bone marrow and made the transplant by endovenous systemic infusion. The results obtained in the 134 patients included and their evolution to three years will be reviewed in this article.

\section{Methods}

\subsection{Subject Recruitment}

With the authorization and control of Institutional Review Board and the approval as compassionate use, a prospective non-randomized phase II clinical trial was designed. We enrolled 134 subjects who met the inclusion criteria for treatment from October 2010 to November 2014. Eligible subjects were: age between 16 and 56 years, undetectable C-peptide level, and chronic type 1 diabetes mellitus for more than 5 years, with negative results of islet cell antibody (ICA) and glutamic acid decarboxylase (GAD) antibody. All enrolled subjects had antecedents of positive results of ICA and GAD antibody. Exclusion criteria: body-mass index (the weight in kilograms divided by the square of the height in meters) $>28$, inadequate renal reserve (serum creatinine $>1.5 \mathrm{mg} / \mathrm{dl}$, creatinine clearance $<80 \mathrm{ml}$ per minute per $1.73 \mathrm{~m}^{2}$ of body-surface area, or albumin level $>300 \mathrm{mg}$ per 24 hour period). Enrolled subjects and their families signed the informed consent.

\subsection{Bone Marrow Cell Preparation and Transplantation}

134 enrolled subjects underwent bone marrow stimulation with $5-10 \mathrm{mg} / \mathrm{kg} /$ day of filgrastim (granulocyte colony-stimulating factor, G-CSF) through subcutaneous injections for four consecutive days. On the 5th day, bone marrow extraction was performed by needle puncture on the anterior iliac crest of the hip with local anesthesia with lidocaine $2 \%$. Then, $300 \mathrm{ml}$ of bone marrow was aspirated and mixed with sodium heparin $(1000 \mathrm{UI} / 40 \mathrm{ml})$. No in vitro expansion procedure or cell culture was performed. 5 - $10 \mathrm{ml}$ of the sample was used for CD34+ cell counting with flow cytometry. The number and types of bone marrow cells were also identified as $\mathrm{CMN}>1 \times 120$ and $\mathrm{CD} 34+>0.37 \times 10.6 / \mathrm{kg}$. The bone marrow cells were injected by a vein of the arm. No immune suppression regimen was processed at pre and post treatment.

\subsection{Study Definitions and Measurements}

Major adverse events were considered as death, bone marrow puncture complications, hematoma requiring surgery or blood transfusion, pulmonary embol- 
ism, acute pancreatitis, emergency abdominal surgery, absence of metabolic stability with major hypoglycaemia, increased measurement results of the ICA and GAD antibody post-transplantation, lymphoproliferative disease, cancer and infections. The primary study endpoint was defined as normalization of C-peptide and $\mathrm{HbAlc}$ with insulin independence at 3 years post-treatment. The $\mathrm{C}$-peptide level in peripheral blood was measured with chemistry electroluminescence after 12-hour fasting. The plasmatic levels of $0.9-4.4 \mathrm{ng} / \mathrm{ml}$ were considered as the normal range with an analytical sensitivity of $0.005-0.040 \mathrm{ng} / \mathrm{ml}$. The HbAlc level was measured by the method of immuno-latex agglutination on particles with the standard values of $4.2 \%-6.2 \%$. The measurement of pancreatic ICA was performed using the ELISA technique. GAD antibodies were identified by radio immuno analysis with the normal value $<1 \mathrm{U} / \mathrm{ml}$ (negative). Reference for these cut-off values was our previous work [39] [40].

\subsection{Follow-Up}

The subjects were phoned every 48 hours in the first week after the cell implantation. Clinical evaluations were performed at baseline (pre-treatment) and months 3, 6, 12, 24, 36 post-treatment, including the measurements of C-peptide, HbA1c, daily insulin dose, ICA, GAD antibody.

\subsection{Statistical Analysis}

Testing was standardized for each sample or examination. Data were presented as means \pm standard deviations $( \pm s)$. Changes of C-peptide and insulin doses between pre- and post-treatment were assessed using paired Wilcoxon signed ranks test and " $<0.05$ " was considered the minimum value of " 0.05 ". Variables between pre and post-treatments of $\mathrm{HbAlc}$ were assessed using paired T-test. All statistical analyses were performed using SPSS 12.0 statistical package. All statistical tests were two-sided and a p-value $<0.05$ was considered statistically significant. The proportion was expected to reach the primary endpoint by $70 \%$ with a confidence interval (CI) of $95 \%$.

\section{Results}

\subsection{Clinical Features}

There were 64 Female and 70 Male patients, the average age of the patients was $36 \pm 20$ years. Diagnosis of type 1 diabetes for 13.9 years on average (2 - 37 years). Body mass index (median) of $28 \mathrm{~kg} / \mathrm{m}^{2}$, normal complete blood count, coagulation and renal function, no lesions in target organs. After bone marrow stimulation, the average proportion of $\mathrm{CD} 34+$ cells in peripheral blood, was $0.07 \%(0.03 \%-0.22 \%)$. Controls of variables were performed at 3, 6, 12, 24 and 36 months after the procedure. All patients signed informed consent.

\subsection{Adverse Events}

Forty-eight subjects displayed bone pain immediately after the cell transplanta- 
tion, which was secondary to bone marrow stimulation. Twenty-two subjects had nausea and twenty-five subjects showed bruising at the site of bone puncture for bone marrow extraction. All these adverse effects were tolerable and relieved in a short time. There were no reports of death, post-transplantation lymphoproliferative diseases, tumors or infections.

\subsection{C-Peptide}

The patients were divided into three groups according to the increase of the peptide c. Less than $0.5 \mathrm{ng} / \mathrm{ml}$ was observed in 134 patients (100\%). Patients with c peptide values between 0.5 and $0.9 \mathrm{ng} / \mathrm{ml}$ and more than $0.9 \mathrm{ng} / \mathrm{ml}$ were not recruited. It was observed 6 months after transplantation in the group of less than $0.5 \mathrm{ng} / \mathrm{ml}$ at $38 \mathrm{p}$. (29\%), in the group between 0.5 and $0.9 \mathrm{ng} / \mathrm{ml}$ at $35 \mathrm{p}$. (26\%) and in the group of more than $0.9 \mathrm{ng} / \mathrm{ml}$ to 61 patients $(45 \%)(\mathrm{P}=0.001, \mathrm{CI}=$ $95 \%)$. At 12 months of follow-up in the group of less than $0.5 \mathrm{ng} / \mathrm{ml}$ at $34 \mathrm{p}$. (25\%), between 0.5 and $0.9 \mathrm{ng} / \mathrm{ml}$ at $50 \mathrm{p}$. (37\%) and in the group of more than $0.9 \mathrm{ng} / \mathrm{ml}$ to 50 patients $(37 \%)(\mathrm{P}=0.001, \mathrm{CI}=95 \%)$. At 24 months in the group of less than $0.5 \mathrm{ng} / \mathrm{ml}$ at $34 \mathrm{p}$. (25\%), between 0.5 and $0.9 \mathrm{ng} / \mathrm{ml}$ at $66 \mathrm{p}$. (49\%) and more than $0.9 \mathrm{ng} / \mathrm{ml}$ to 53 patients $(39 \%)(\mathrm{P}=0.001, \mathrm{CI}=95 \%)$. At 36 months in the group of less than $0.5 \mathrm{ng} / \mathrm{ml}$ at $48 \mathrm{p}$. (36\%), between 0.5 and 0.9 $\mathrm{ng} / \mathrm{ml}$ at $35 \mathrm{p}$. $(26 \%)$ and more than $0.9 \mathrm{ng} / \mathrm{ml}$ to 51 patients $(38 \%)(\mathrm{P}=0.001$, $\mathrm{CI}=95 \%)($ Figure 1$)$.

\subsection{Daily Insulin Dose}

The patients were divided into four groups according to the post-transplant evolution of the daily insulin dose. Before treatment, in the group of less than 30 units at 54 p. (40\%), in the group between 30 and 40 to 53 p. (39\%) and in the group of more than 40 to 28 patients (21\%), no patients were recruited who did not use insulin daily. It was observed 6 months after transplantation in the group of less than 30 units at $13 \mathrm{p}$. (10\%), in the group between 30 and 40 units at $55 \mathrm{p}$. (41\%) and in the group of more than 40 units to 5 patients (4\%), 61 patients did not use insulin (45\%) $(\mathrm{P}=0.001, \mathrm{CI}=95 \%)$. At 12 months of follow-up in the group of less than 30 units at 13 p. (10\%), between 30 and 40 units at 58 p. (43\%) and in the group of more than 40 units to 3 patients (2\%), 60 patients did not

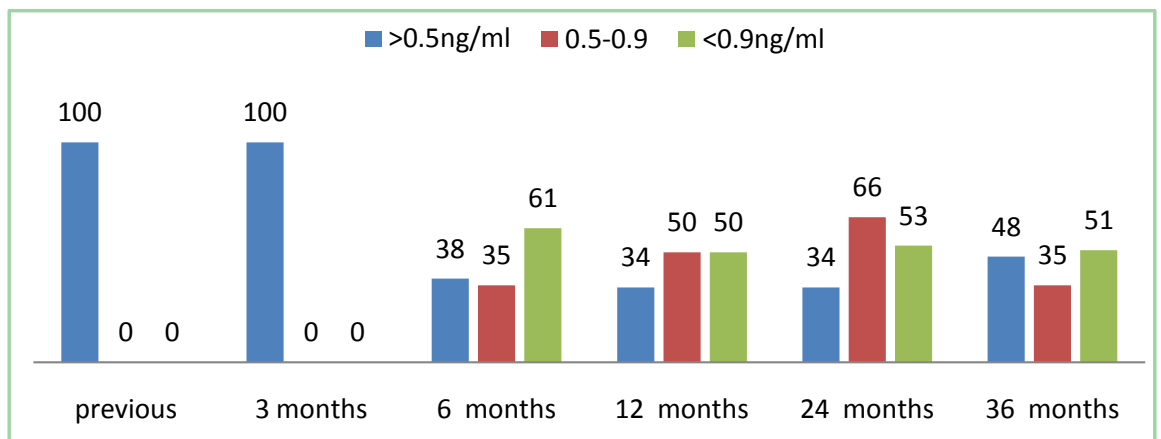

Figure 1. C Peptide Control-134 patients treated-36 month follow up. 
use insulin $(45 \%)(\mathrm{P}=0.001, \mathrm{CI}=95 \%)$. At 24 months in the group of less than 30 units at $15 \mathrm{p}$. (11\%), between 30 and 40 units at $57 \mathrm{p}$. (42\%) and more than 40 units to 4 patients (3\%), 58 patients did not use insulin (43\%) $(\mathrm{P}=0.001, \mathrm{CI}=$ $95 \%)$. At 36 months in the group of less than 30 units at 19 p. (14\%), between 30 and 40 units at 58 p. (43\%) and more than 40 units in 4 patients (3\%), 53 patients did not use insulin (39\%) $(\mathrm{P}=0.001, \mathrm{CI}=95 \%)$ (Figure 2$)$.

\subsection{Glycated Hemoglobin (HbA1c)}

Similarly, patients were divided into three groups according to the last control of glycosylated hemoglobin A1C. Less than 7\% was observed in 25 patients (18\%). Between 7 and $9 \%$ in 88 p. (65\%) and more than $9 \%$ in 21 p. (15\%). It was observed 6 months after the transplant in the group of less than $7 \%$ at 68 p. (50\%), in the group between 7 and $9 \%$ at 63 p. (47\%) and in the group of more than $9 \%$ to 3 patients $(2 \%)(\mathrm{P}=0.001, \mathrm{CI}=95 \%)$. At 12 months of follow-up in the group of less than $7 \%$ at $90 \mathrm{p}$. (67\%), between 7 and $9 \%$ at $41 \mathrm{p}(30 \%)$. and in the group of more than $9 \%$ to 3 patients $(2 \%)(\mathrm{P}=0.001, \mathrm{CI}=95 \%)$. At 24 months in the group of less than $7 \%$ to 92 p. (68\%), between 7 and $9 \%$ to 39 p. (29\%) and more than $9 \%$ to 3 patients (2\%). At 36 months in the group of less than $7 \%$ at $85 \mathrm{p}$. (63\%), between 7 and $9 \%$ at 48 p. (36\%) and more than $9 \%$ to 1 patient $(0.7 \%)(\mathrm{P}$ $=0.001, \mathrm{CI}=95 \%)($ Figure 3$)$.

\subsection{Blood Glucose}

The patients were divided into three groups according to the usual control of fasting blood glucose in the last three months. Less than $150 \mathrm{mg} / \mathrm{ml}$ was observed in 36 patients (26\%). Between 150 and 250 in 68 p. (50\%) and more than

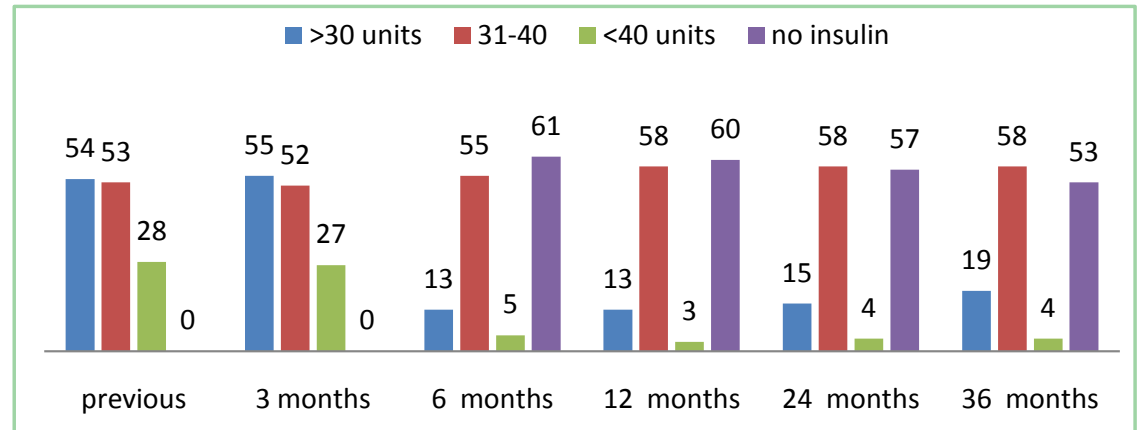

Figure 2. Insulin Units Daly Control-134 patients treated-36 month follow up.

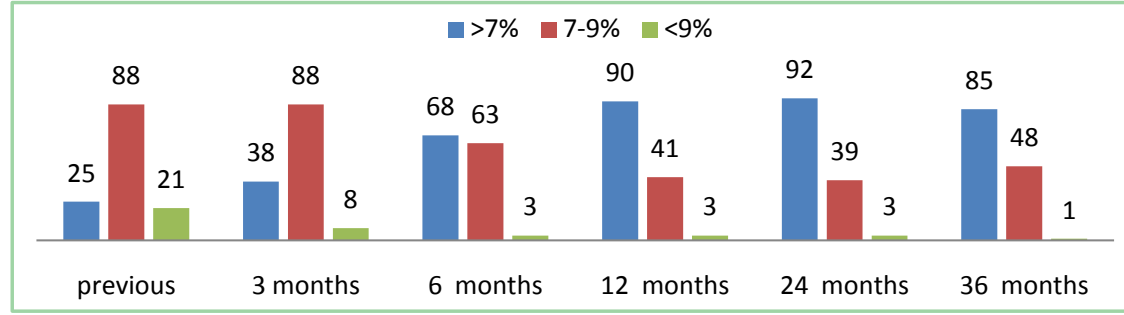

Figure 3. A1C Control-134 patients treated-36 month follow up. 
250 in 30 p. (22\%) It was observed at 6 months post-transplant in the group of less than $150 \mathrm{mg} / \mathrm{ml}$ at $60 \mathrm{p}$. (44\%), in the group between 150 and 250 to $67 \mathrm{p}$. (50\%) and in the group of more than $250 \mathrm{mg} / \mathrm{ml}$ to 7 patients (5\%). At 12 months of follow-up in the group of less than $150 \mathrm{mg} / \mathrm{ml}$ at $82 \mathrm{p}$. (61\%), between 150 and 250 to $40 \mathrm{p}$. (30\%) and in the group of more than $250 \mathrm{mg} / \mathrm{ml}$ to $12 \mathrm{pa}-$ tients (9\%). At 24 months in the group of less than $150 \mathrm{mg} / \mathrm{ml}$ at $67 \mathrm{p.}(50 \%)$, between 150 and 250 to $48 \mathrm{p}$. (36\%) and more than $250 \mathrm{mg} / \mathrm{ml}$ to 19 patients (14\%). At 36 months in the group of less than $150 \mathrm{mg} / \mathrm{ml}$ at $67 \mathrm{p}$. 50, between 150 and 250 to 48 p. 36 and more than $250 \mathrm{mg} / \mathrm{ml}$ to 19 patients $(14 \%)(\mathrm{P}=$ $0.001, \mathrm{CI}=95 \%)$ (Figure 4 ).

\subsection{Sensitization}

All enrolled subjects had antecedents of positive results of ICA and GAD antibody when diagnosed and negative results when enrolled in this study. Negative results of ICA and GAD antibody were detected during the follow-up at 6, 12, 24 and 36 months.

\section{Discussion}

Diabetes, recently declared a pandemic by the World Health Organization, is a risk factor for increased mortality and morbidity. To short and long term, is an important problem for global public health [41] [42] [43]. It is known that about 30 million people in the United States have diabetes and approximately 86 million have pre-diabetes. One out of every three dollars of the health system is spent on diabetes with a total cost in the US of 322 billion dollars per year. However, the situation will not improve in the next few years; even will be worse according to American Diabetes Association estimates.

Recently, several scientific publications demonstrated that intensive therapy for type 1 diabetes delayed the development of microvascular and neuropathic complications. This work is published that shows that thirty years of excellent against poor glycemic control reduced the incidence of retinopathy requiring laser therapy ( $5 \%$ vs. $45 \%)$, clinical neuropathy ( $15 \%$ vs. $50 \%)$ and death (6\% vs. $20 \%)$. But no significant change in end-stage renal disease (0\% vs. $5 \%$ ), myocardial infarction ( $3 \%$ vs. $5 \%)$ and stroke $(0.4 \%$ vs. $2 \%)$. Based on these reports we

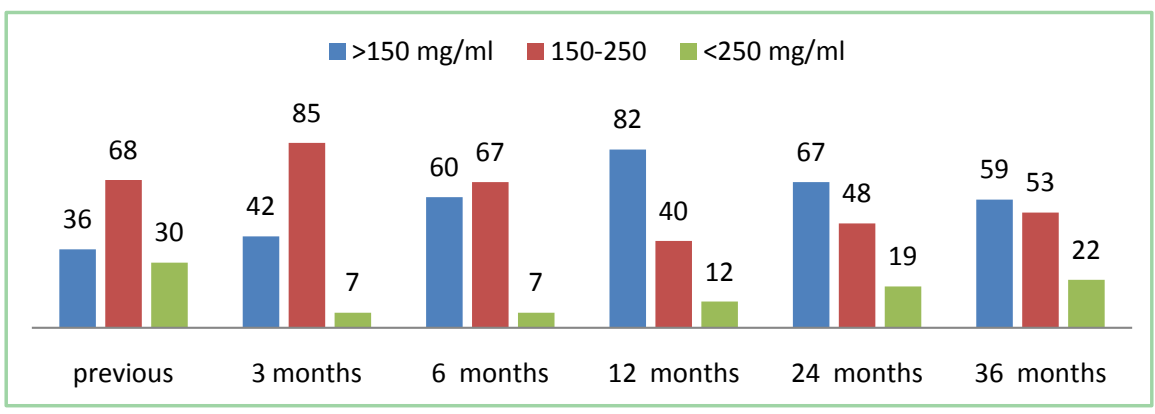

Figure 4. Glycemic Control-134 patients treated-36 month follow up. 
can say that the use of insulin in a strict way does not solve the patient's long-term problem [44]. Even a 30-year cost-effectiveness analysis shows that strict insulin therapy and intensive control in type 1 diabetes is not cost-effective [45].

We believe that biological treatments can help control glycemia, such as the use of stem cells and their bioproducts, and they are a valid alternative. We believe that the only option with scientific support is the transplantation of bone marrow stem cells. The results demonstrated that the bone marrow stem cells transplant, stimulated with filgrastim without immunospupression, by venous infusion is safe and easy to perform. No severe adverse events have been reported. The endocrine function of pancreas was reactivated after bone marrow cell transplantation as shown by the increased level of C-peptide in 94 patients (71\%) at 6 months of follow up, demonstrating that the secretion of pancreatic insulin was reassumed. The decreased daily insulin dose and $\mathrm{HbAlc}$ level indicated that metabolic control was reestablished. During follow-ups, the studied population showed a significant increase in c peptide, in which $50 \%$ responders subjects showed a normalization in plasma levels. This clinical improvement was evident with episodes of hypoglycemia but never severe. We also consider significant the fact that patients obtain sustained metabolic control and stabilization of their parameters and do not present episodes of hyperglycemia.

The results evidenced a beneficial effect of the bone marrow cell implantation on subjects with chronic type 1 diabetes, which was more evident in those patients who used low doses of insulin before transplantation. This makes us think that the pancreas still had a residual function and that the bone marrow cells managed to reactivate. The mechanisms of action of the stem cells were extensively described in vitro. The reactivation of quiescent pancreatic stem cells and migration, aggregation and differentiation of stem cells of the medial bone can be mediated by transplanted stem cells, growth factors, cytokines and chemokines produced by these cells. The pancreatic stem cells and transplanted bone marrow stem cells might be recruited through the mediation of the pancreatic cytokines and ultimately initiated cell regeneration by differentiation.

We could think that the patients who evolved favorably after the transplant had a high level of chemokines in the pancreatic area, regardless of the time of evolution of the disease, and that this could be a variable of success of the treatment.

This hypothesis is based on the work of Lanus et al. [14] that obtained stem cells from male mice expressing the CRE-LoxO system with green fluorescent protein and were injected into the female mice, which were lethally irradiated to stop secreting insulin. After 4 to 6 weeks, islets of Langerhans with Y chromosome marked with fluorescein were observed in the pancreas of the female mice. This experiment was the first one to describe the cellular migration and its differentiation without evidence of cellular fusion.

In our initial experience 15 years ago [39] [40], we performed a bone marrow stimulation with filgrastim with low doses, and we extracted an average volume of $120 \mathrm{ml}$ of bone marrow by puncture, in addition we performed the cellular 
implant by a selective arterial catheterization of the pancreatic artery, without immunosuppression, and we observed an increase in C-peptide at six months after cell transplantation, which remained at a significant level until three years after treatment.

In our current work the bone marrow stimulation is also done with filgrastim but at maximum possible doses, and the bone marrow extraction is performed by multiple hip punctures to reach a volume of $300 \mathrm{ml}$ and we do the transplant by a systemic venous infusion, also without using immune suppression. The results in terms of peptide elevation $c$ resulted superior with our new technique, patients normalized glycosylated hemoglobin and fasting daily glucose controls, decreasing and even leaving the daily dose of insulin. It is also interesting to comment on the persistence over time of the results that three years after transplantation are still significant. The majority of patients continue with elevated c-peptide and glycosylated hemoglobin at normal values. Our experience increasing the volume of bone marrow infused was positive and improved the results in a large number of patients.

Our experience is one of the largest presented and matches the results published by several authors in the form of three meta-analyzes that analyzed more than 1500 patients and dozens of scientific studies where different cell types were used, in different types of diabetes, and whose conclusions was very important in showing a clear benefit and safety [46] [47] [48].

In addition, the technique of systemic venous transplantation in this study evidenced that the infused cells manage to reach the pancreas and obtain significant clinical modifications. Although bone marrow implantation by catheterization could generate a high number of bone marrow stem cells in the affected area, our comparative results between both techniques would not be conclusive in favor of the selective endovascular implant. It can also be considerable that the transplantation of cells through a systemic intravenous injection can achieve a high and effective number of cells in the affected tissues, and consequently there are obvious clinical results. We think that the alternative of endovenous systemic infusion of the bone marrow implies a greater accessibility of the treatment, a lower requirement of technology and potential vascular access complications. Our results are in contrast to those of a study that showed that $70 \%$ of the stem cells released in the venous circulation were stopped in the lung and only a small amount of cells reached the heart, kidneys and liver [49]. We consider then that the pulmonary filter, although it is anatomically and histologically evident, is not from the clinical point of view. We believe that others bone marrow cells can work as regeneratives and not only stem cells are important in this repair. A percentage of subjects showed a metabolic degradation during the three-year follow-up, with decreases in the levels obtained after transplantation of C-peptide and required a new increase in exogenous insulin dose after three years after treatment. This indicated the destruction of new pancreatic $\beta$ cells, but the mechanism of cell damage has not been clarified. We can say that this clinical evolution could not be justified with a new autoimmune antibody attack, 
since the ICA and GAD antibodies were always negative during the three-year follow-up. We could conjecture the origin of the descent of the c peptide post transplant with a mechanism of cellular apoptosis related to the inverse relationship between the new cell growth and the low vascularization of the pancreatic tissue. Perhaps the use of specifically angiogenic cells helps to improve graft survival and that support the hypotesis about the importance of other cells into bone marrow, grow factors and relations between them.

\section{Conclusion}

This study demonstrates that autologous bone marrow cell transplantation, without immune suppression, is a safe and effective therapeutic strategy for patients with chronic type 1 diabetes. The results of the three years of follow-up demonstrated safety since no adverse events were observed, and also showed the restoration of pancreatic function with a significant increase in C-peptide and, consequently, a significant decrease in the daily dose of exogenous insulin. This effect partially disappears during the three years of follow-up without an increase in ICA and GAD antibodies. This treatment is an alternative in patients treated with low doses of insulin or with metabolic instability where an evident improvement in the quality of life of patients with type 1 diabetes was observed.

\section{Source of Support}

Departmental sources.

\section{Conflicts of Interest}

The authors declare no conflicts of interest regarding the publication of this paper.

\section{References}

[1] Gianani, R., Campbell-Thompson, M., Sarkar, S.A., et al. (2010) Dimorphic Histopathology of Long-Standing Childhood-Onset Diabetes. Diabetologia, 53, 690-698. https://doi.org/10.1007/s00125-009-1642-y

[2] Madsbad, S., Krarup, T., Regeur, L., Faber, O.K. and Binder, C. (1980) Insulin Secretory Reserve in Insulin Dependent Patients at Time of Diagnosis and the First 180 Days of Insulin Treatment. Acta Endocrinologica, 95, 359-363. https://doi.org/10.1530/acta.0.0950359

[3] Steele, C., Hagopian, W.A., Gitelman, S., et al. (2004) Insulin Secretion in Type 1 Diabetes. Diabetes, 53, 426-433. https://doi.org/10.2337/diabetes.53.2.426

[4] Eff, C.H., Faber, O. and Deckert, T. (1978) Persistent Insulin Secretion, Assessed by Plasma C-Peptide Estimation in Long-Term Juvenile Diabetics with a Low Insulin Requirement. Diabetologia, 15, 169-172. https://doi.org/10.1007/BF00421234

[5] Nakanishi, K. and Watanabe, C. (2008) Rate of $\beta$-Cell Destruction in Type 1 Diabetes Influences the Development of Diabetic Retinopathy: Protective Effect of Residual $\beta$-Cell Function for More than 10 Years. The Journal of Clinical Endocrinology \& Metabolism, 93, 4759-4766. https://doi.org/10.1210/jc.2008-1209

[6] Liu, E.H., Digon, B.J., Hirshberg, B., et al. (2009) Pancreatic Beta Cell Function 
Persists in Many Patients with Chronic Type 1 Diabetes, but Is Not Dramatically Improved by Prolonged Immunosuppression and Euglycaemia from a Beta Cell Allograft. Diabetologia, 52, 1369-1380. https://doi.org/10.1007/s00125-009-1342-7

[7] Madsbad, S., Faber, O.K., Binder, C., McNair, P., Christiansen, C. and Transbøl, I. (1978) Prevalence of Residual Beta-Cell Function in Insulin Dependent Diabetics in Relation to Age at Onset and Duration of Diabetes. Diabetes, 27, 262-264. https://doi.org/10.2337/diab.27.1.S262

[8] Ramiya, V.K., Maraist, M., Arfors, K.E., Schatz, D.A., Peck, A.B. and Cornelius, J.G. (2000) Reversal of Insulin-Dependent Diabetes Using Islets Generated in Vitro from Pancreatic Stem Cells. Nature Medicine, 6, 278-282.

https://doi.org/10.1038/73128

[9] Dor, Y., Brown, J., Martinez, O.I. and Melton, D.A. (2004) Adult Pancreatic-Cells Are Formed by self-Duplication Rather than Stem-Cell Differentiation. Nature, 429, 41-46. https://doi.org/10.1038/nature02520

[10] De la Tour, D., Halvorsen, T., Demeterco, C., Tyrberg, B., Itkin-Ansari, P., Loy, M., Loo, S.J., Hao, E., Bossie, S. and Levine, F. (2001) Beta-Cell Differentiation from a Human Pancreatic Cell Line in Vitro and in Vivo. Molecular Endocrinology, 15, 476-483. https://doi.org/10.1210/mend.15.3.0604

[11] Chen, L.B., Jiang, X.B. and Yang, L. (2004) Differentiation of Rat Marrow Mesenchymal Stem Cells into Pancreatic Islet Beta-Cells. World Journal of Gastroenterology, 10, 3016-3020. https://doi.org/10.3748/wjg.v10.i20.3016

[12] Venstrom, J.M., McBride, M.A., Rother, K.I., Hirshberg, B., Orchard, T.J. and Harlan, D.M. (2003) Survival after Pancreas Transplantation in Subjects with Diabetes and Preserved Kidney Function. Journal of the American Medical Association, 290, 2817-2823. https://doi.org/10.1001/jama.290.21.2817

[13] Shapiro, A.M.J., Ricordi, C., Hering, B.J., Auchincloss, H., Lindblad, R., Robertson, R.P., Secchi, A., Brendel, M.D., Berney, T., Brennan, D.C., Cagliero, E., Alejandro, R., Ryan, E.A., DiMercurio, B., Morel, P., Polonsky, K.S., Reems, J.A., Bretzel, R.G., Bertuzzi, F., Froud, T., Kandaswamy, R., Sutherland, D.E.R., Eisenbarth, G., Segal, M., Preiksaitis, J., Korbutt, G.S., Barton, F.B., Viviano, L., Seyfert-Margolis, V., Bluestone, J. and Lakey, J.R.T. (2006) International Trial of the Edmonton Protocol for Islet Transplantation. The New England Journal of Medicine, 355, 1318-1330. https://doi.org/10.1056/NEJMoa061267

[14] Ianus, A., Holz, G., Theise, N.D. and Hussain, M. (2003) In Vivo Derivation of Glucose-Competent Pancreatic Endocrine Cells from Bone Marrow without Evidence of Cell Fusion. Journal of Clinical Investigation, 111, 843-850.

https://doi.org/10.1172/JCI200316502

[15] Hakuno, D., Fukuda, K., Makino, S., et al. (2002) Bone Marrow-Derived Regenerated Cardiomyocytes (CMG Cells) Express Functional Adrenergic and Muscarinic Receptors. Circulation, 105, 380-386. https://doi.org/10.1161/hc0302.102593

[16] Laflamme, M.A., Myerson, D., Saffitz, J.E. and Murry, C.E. (2000) Evidence for Cardiomyocyte Repopulation by Extracardiac Progenitors in Transplanted Human Hearts. Circulation Research, 90, 634-640. https://doi.org/10.1161/01.RES.0000014822.62629.EB

[17] Alison, M.R., Poulsom, R., Jeffery, R., Dhillon, A.P., Quaglia, A., Jacob, J., Novelli, M., Prentice, G., Williamson, J. and Wright, N.A. (2000) Hepatocytes from Non-Hepatic Adult Stem Cells. Nature, 406, 257. https://doi.org/10.1038/35018642

[18] Poulsom, R., Forbes, S.J., Hodivala-Dilke, K., Ryan, E., Wyles, S., Navaratnarasah, S., Jeffery, R., Hunt, T., Alison, M., Cook, T., Pusey, C. and Wright, N.A. (2001) 
Bone Marrow Contributes to Renal Parenchymal Turnover and Regeneration. The Journal of Pathology, 195, 229-235. https://doi.org/10.1002/path.976

[19] Messier, B. and Leblond, C. P. (1960) Cell Proliferation and Migration as Revealed by Radioautography after Injection of Thymidine- $\mathrm{H}^{3}$ into Male Rats and Mice. American Journal of Anatomy, 106, 247-285. https://doi.org/10.1002/aja.1001060305

[20] Bonner-Weir, S., Baxter, L.A., Schuppin, G.T. and Smith, F.E.A (1993) Second Pathway for Regeneration of Adult Exocrine and Endocrine Pancreas: A Possible Recapitulation of Embryonic Development. Diabetes, 42, 1715-1720.

https://doi.org/10.2337/diab.42.12.1715

[21] Bonner-Weir, S. (2000) Life and Death of the Pancreatic Beta Cells. Trends in Endocrinology \& Metabolism, 11, 375-378. https://doi.org/10.1016/S1043-2760(00)00305-2

[22] Finegood, D.T., Scaglia, L. and Bonner-Weir, S. (1995) Dynamics of Beta-Cell Mass in the Growing Rat Pancreas: Estimation with a Simple Mathematical Model. Diabetes, 44, 249-256.

[23] Assmus, B., Schächinger, V. and Teupe, C. (2002) Transplantation of Progenitor Cells and Regeneration Enhancement in Acute Myocardial Infarction (TOPCARE-AMI). Circulation, 106, 3009-3017. https://doi.org/10.1161/01.CIR.0000043246.74879.CD

[24] Strauer, B.E., Brehm, M., Zeus, T., Kostering, M., Hernández, A., Sorg, R.V., et al. (2002) Repair of Infarcted Myocardium by Autologous Intracoronary Mononuclear Bone Marrow Cell Transplantation in Humans. Circulation, 106, 1913-1918. https://doi.org/10.1161/01.CIR.0000034046.87607.1C

[25] Fernández-Avilés, F., San Román, J.A., García-Frade, J., Fernández, M.E., Penarrubia, M.J., De la Fuente, L., et al. (2004) Experimental and Clinical Regenerative Capability of Human Bone Marrow Cells after Myocardial Infarction. Circulation Research, 95, 742-748. https://doi.org/10.1161/01.RES.0000144798.54040.ed

[26] Wollert, K.C., Meyer, G.P., Lotz, J., Ringes-Lichtenberg, S., Lippolt, P., Breidenbach, C., et al. (2004) Intracoronary Autologous Bone-Marrow Cell Transfer after Myocardial Infarction: The BOOST Randomised Controlled Clinical Trial. Lancet, 364, 141-148. https://doi.org/10.1016/S0140-6736(04)16626-9

[27] Schachinger, V., Erbs, S., Elsasser, A., Haberbosch, W., Hambrecht, R., Holschermann, H., et al. (2006) Intracoronary Bone Marrow-Derived Progenitor Cells in Acute Myocardial Infarction. The New England Journal of Medicine, 355, 1210-1221.

https://doi.org/10.1056/NEJMoa060186

[28] Hahn, T., Wall, D., Camitta, B., et al. (2005) The Role of Cytotoxic Therapy with Hematopoietic Stem Cell Transplantation in the Therapy of Acute Lymphoblastic Leukemia in Children: An Evidence-Based Review. Biology of Blood and Marrow Transplantation, 11, 823-861. https://doi.org/10.1016/j.bbmt.2005.08.035

[29] Sanders, J.E., Im, H.J., Hoffmeister, P.A., et al. (2005) Allogeneic Hematopoietic Stem Cell Transplantation for Infants with Acute Lymphoblastic Leukemia. Blood, 105, 3749-3756. https://doi.org/10.1182/blood-2004-08-3312

[30] Centeno, C.J., Schultz, J.R., Cheever, M., Robinson, B., Freeman, M. and Marasco, W. (2010) Safety and Complications Reporting on the Re-Implantation of Culture-Expanded Mesenchymal Stem Cells Using Autologous Platelet Lysate Technique. Current Stem Cell Research \& Therapy, 5, 81-93. https://doi.org/10.2174/157488810790442796

[31] Ripoll, P.L., De Prado, M. and Yelo, J. (2009) Osteonecrosis of the Knee: Perfusion of Iliac Crest Mesenchymal Cells. Trauma, 20, 211-220. 
[32] Pesce, M., Orlandi, A., Iachininoto, M.G., Straino, S., Torella, A.R., Rizzut, V., et al. (2003) Myoendothelial Differentiation of Human Umbilical Cord Blood Derived Stem Cells in Ischemic Limb Tissues. Circulation Research, 93, 51-62. https://doi.org/10.1161/01.RES.0000090624.04507.45

[33] Vicario, J.H., Campo, C.D., Gerardo, L.E., Pfeffer, H., Ortega, H.H. and Agustín Yosviak, A. (2008) Angiogenesis in Severe Peripheral Arterial Disease with Intra-Arterial Administration of Unfractionated Autologous Bone Marrow. Phase I. Revista de la Federacion Argentina de Cardiologia, Buenos Aires.

[34] Huang, P.P., Li, S.Z., Han, M.Z., Xiao, Z.J., Yang, R.C., Qiu, et al. (2004) Autologous Transplantation of Peripherals Blood Stem Cells as an Effective Therapeutic Approach for Severe Arteriosclerosis Obliterans of Lower Extremities. Journal of Thrombosis and Haemostasis, 91, 606-609. https://doi.org/10.1160/TH03-06-0343

[35] Huang, P., Li, S., Han, M., Xiao, Z., Yang, R. and Han, Z.C. (2005) Autologous Transplantation of Granulocyte Colony-Stimulating Factor-Mobilized Peripheral Mononuclear Cell Improves Critical Limb Ischemia in Diabetes. Diabetes Care, 28, 2155-2160. https://doi.org/10.2337/diacare.28.9.2155

[36] Couri, C., Oliveira, M., Stracieri, A., Moraes, D., Pieroni, F., Barros, G., Madeira, M.I., Malmegrim, K., Foss-Freitas, M., Simões, B., Martinez, E., Foss, M., Burt, R.K. and Voltarelli, J.C. (2009) C-Peptide Levels and Insulin Independence Following Autologous Nonmyeloablative Hematopoietic Stem Cell Transplantation in Newly Diagnosed Type 1 Diabetes Mellitus. JAMA, 301, 1573-1579.

https://doi.org/10.1001/jama.2009.470

[37] Gu, W.Q., Hu, J., Wang, W.Q., Li, L.R., Tang, W., Sun, S.Y., Cui, W.J., et al. (2012) Diabetic Ketoacidosis at Diagnosis Influences Complete Remission after Treatment with Hematopoietic Stem Cell Transplantation in Adolescents with Type 1 Diabetes. Diabetes Care, 35, 1413-1419. https://doi.org/10.2337/dc11-2161

[38] Fotino, C., Ricordi, C., Lauriola, V., Alejandro, R. and Pileggi, A. (2012) Bone Marrow-Derived Stem Cell Transplantation for the Treatment of Insulin-Dependent Diabetes. The Review of Diabetic Studies, 7, 144-157.

https://doi.org/10.1900/RDS.2010.7.144

[39] Mesples, A.D., Pretiñe, B. and Bellomo, R. (2007) Treatment of Type 1 Diabetes Mellitus with Pancreatic Implant of Autologous Adult Stem Cell. Endocrinología $y$ Nutrición, 54, 512-518. https://doi.org/10.1016/S1575-0922(07)71497-3

[40] Mesples, A., Jiang, S., Zhang, Y., Luo, Z.X. and Hu, X. (2013) C-Peptide Increase in Chronic Type 1 Diabetic Patients Treated with Autologous Bone Marrow Cell Transplantation through Pancreatic Artery Catheterization: Three Years Follow-Up. Stem Cell Discovery, 3, 56-63. https://doi.org/10.4236/scd.2013.31009

[41] Sitio OMS, Press Release, November 18, 2004, Ginebra.

[42] The Diabetes Control and Complications Trial Research Group (1993) The Effect of Intensive Treatment of Diabetes on the Development and Progression of Long-Term Complications in Insulin-Dependent Diabetes Mellitus. New England Journal of Medicine, 329, 977-986. https://doi.org/10.1056/NEJM199309303291401

[43] (1997) Report of the Expert Committee on the Diagnosis and Classification of Diabetes Mellitus. Diabetes Care, 20, 1183-1197.

https://doi.org/10.2337/diacare.20.7.1183

[44] Herman, W.H., Braffett, B.H., Kuo, S., Lee, J.M., Brandle, M., Jacobson, A.M., Lisa A., Lachin, J.M. and The Diabetes Control and Complications Trial/Epidemiology of Interventions and Complications (DCCT/EDIC) Research Group (2014) What Are the Clinical, Quality-of-Life, and Cost Consequences of 30 Years of Excellent vs. 
Poor Glycemic Control in Type 1 Diabetes? Diabetes Care, 37, 9-16.

[45] Herman, W.H., Braffett, B.H., Kuo, S., Lee, J.M., Brandle, M., Jacobson, A.M., Lisa A. and Lachin, J.M. (2018) The 30-Year Cost-Effectiveness of Alternative Strategies to Achieve Excellent Glycemic Control in Type 1 Diabetes: An Economic Simulation Informed by the Results of the Diabetes Control and Complications Trial/Epidemiology of Diabetes Interventions and Complications (DCCT/EDIC). Journal of Diabetes and its Complications, 32, 934-939.

https://doi.org/10.1016/j.jdiacomp.2018.06.005

[46] El-Badawy, A. and El-Badri, N. (2016) Clinical Efficacy of Stem Cell Therapy for Diabetes Mellitus: A MetaAnalysis. PLoS ONE, 11, e0151938.

https://doi.org/10.1371/journal.pone.0151938

[47] Cao, J.X., Zhao, Y.Q. and Ding, G.C. (2016) Evaluation of the Clinical Efficacy of Stem Cell Transplantation in Patients with Type 1 Diabetes Mellitus. International Journal of Clinical and Experimental Medicine, 9, 19034-19051.

[48] Wang, Z.X., Cao, J.X., Li, D., Zhang, X.Y., Liu, J.L., Li, J.L., Wang, M., Liu, Y.X., Xu, B.L. and Wang, H.B. (2015) Clinical Efficacy of Autologous Stem Cell Transplantation for the Treatment of Patients with Type 2 Diabetes Mellitus: A Meta-Analysis. Cytotherapy, 17, 956-968. https://doi.org/10.1016/j.jcyt.2015.02.014

[49] Herreros, J., Chaques, J., Trainini, J., Ponton, A., Sarralde, A. and Genovese, J. (2011) Cardiac Cell Regeneration. Circle Cardiovascular, 18, 207-215. https://doi.org/10.1016/S1134-0096(11)70056-0 